\title{
PENERAPAN PEMBELAJARAN PEER INSTRUCTION WITH STRUCTURED INQUIRY (PISI) UNTUK MENINGKATKAN KEMAMPUAN PEMAHAMAN MATEMATIS SISWA
}

\author{
Angra Meta Ruswana \\ Program Studi Pendidikan Matematika, FKIP, Universitas Galuh, \\ Jln. R.E. Martadinatan No 150 Ciamis, 46251, Ciamis \\ e-mail: angra.meta@gmail.com
}

\begin{abstract}
ABSTRAK
Abstrak. Penelitian ini dilatarbelakangi oleh adanya fakta bahwa proses pembelajaran yang dilakukan sampai saat ini adalah pembelajaran konvensional yang membuat siswa menjadi subjek yang kurang aktif sehingga kemampuan pemahaman siswa masih berada pada kategori rendah. Penelitian ini bertujuan untuk mengetahui peningkatan kemampuan pemahaman siswa yang memperoleh pembelajaran Peer Instruction with Structured Inquiry (PISI) dibandingkan dengan siswa yang memperoleh pembelajaran konvensional serta dikaji pula sikap siswa terhadap pembelajaran PISI. Metode penelitian yang digunakan adalah quasi experiment dengan desain kelompok kontrol non ekuivalen. Populasinya siswa kelas VIII pada salah satu SMP di Ciamis dan sampelnya adalah siswa kelas VIII-B sebagai kelas eksperimen (kelas PISI) dan VIII-C sebagai kelas kontrol (kelas konvensional) yang dipilih dengan cara purposive sampling. Alat uji yang digunakan adalah instrumen tes berupa tes kemampuan pemahaman matematis dan instrumen non tes berupa skala sikap, wawancara dan lembar observasi. Berdasarkan pengolahan data menggunakan uji gain ternormalisasi dan uji statistik berupa uji t' dan uji Mann-Whitney, diperoleh hasil: 1) Peningkatan kemampuan pemahaman matematis siswa yang memperoleh pembelajaran PISI lebih baik daripada siswa yang mendapat pembelajaran konvensional, namun masih berada pada klasifikasi sedang. Berdasarkan indikator pemahaman matematis yang diukur, peningkatan kemampuan pemahaman induktif berada pada klasifikasi sedang. 2) Secara keseluruhan, sikap siswa yang mendapat pembelajaran PISI menunjukkan sikap yang positif.
\end{abstract}

Kata Kunci: Peer Instruction with Structured Inquiry (PISI), Kemampuan Pemahaman Matematis, Sikap Siswa.

\section{PENDAHULUAN}

Salah satu disiplin ilmu yang mempunyai peranan penting dalam pendidikan dan dalam menentukan masa depan adalah matematika. Mengingat pentingnya matematika dalam ilmu pengetahuan serta kehidupan pada umumnya, maka matematika perlu dipahami oleh semua lapisan masyarakat terutama siswa sekolah formal. Hal ini dilandaskan dari asumsi bahwa penguasaan matematika akan menjadi salah satu sarana untuk mempelajari bidang studi lainnya, baik itu pada jenjang pendidikan yang sama maupun jenjang pendidikan yang lebih tinggi.

Kurikulum Tingkat Satuan Pendidikan (KTSP) (Depdiknas, 2006) mengungkapkan tujuan diberikan mata pelajaran matematika di sekolah adalah agar para peserta didik memiliki kemampuan sebagai berikut : 
1) memahami konsep matematika, menjelaskan antar konsep dan mengaplikasikan konsep atau algoritma, secara luwes, akurat, efisien dan tepat dalam pemecahan masalah, 2) menggunakan penalaran pada pola dan sifat, melakukan manipulasi matematika dalam membuat generalisasi, menyusun bukti atau menjelaskan gagasan dan pernyataan matematika, 3) memecahkan masalah yang meliputi kemampuan memahami masalah, merancang teknik matematika, menyelesaikan teknik dan menafsir solusi yang diperoleh. 4) mengkomunikasikan gagasan dengan simbol, tabel, diagram atau media lain untuk memperjelas keadaan atau masalah. 5) memiliki sikap menghargai kegunaan matematika dalam kehidupan yaitu memiliki rasa ingin tahu, perhatian dan minat dalam mempelajari matematika, serta sikap ulet dan percaya diri dalam pemecahan masalah.

Kemampuan pemahaman matematis adalah salah satu tujuan yang harus dikuasai siswa. Pemahaman berkaitan dengan penguasaan atau mengerti tentang sesuatu. Kemampuan pemahaman merupakan kemampuan paling mendasar yang harus dimiliki siswa karena kemampuan ini bisa menunjang siswa untuk mencapai kemampuan berpikir matematis lainnya.

Siswa yang telah memahami konsep matematis akan lebih mudah dalam mempelajari ilmu matematika. Sumarmo (2003) menyatakan bahwa pemahaman matematis penting dimiliki siswa karena diperlukan untuk menyelesaikan masalah matematika, masalah dalam disiplin ilmu lain, dan masalah dalam kehidupan seharihari, yang merupakan visi pengembangan pembelajaran matematika untuk memenuhi kehidupan masa kini.

Namun sebagian besar siswa masih belum mampu menyelesaikan soal matematika dengan baik karena kemampuan pemahamannya belum berkembang dengan baik. Sesuai yang diungkapkan oleh Hendriana (2009) bahwa kemampuan pemahaman matematis siswa tidak berkembang sebagaimana mestinya. Sebagian besar siswa merasa kesulitan dalam memahami dan menyerap konsepkonsep matematika yang diberikan oleh guru.

Menurut menurut Zulkardi (Hamidah, 2011) banyak faktor yang menyebabkan rendahnya pemahaman matematis siswa, salah satu faktornya yaitu faktor yang berkaitan dengan pembelajaran di sekolah, misalnya metode mengajar matematika yang masih terpusat pada guru, sementara siswa cenderung pasif. Hasil penelitian Sumarmo (Oktavien, 2012) mengungkapkan bahwa pada umumnya kondisi saat ini di lapangan, pembelajaran matematika kurang melibatkan aktivitas siswa secara optimal sehingga kurang aktif dalam belajar. Hal ini sesuai dengan pendapat Ruseffendi (2006) juga menyatakan bahwa selama ini dalam proses pembelajaran matematika di kelas, pada umumnya siswa mempelajari matematika hanya diberitahu oleh gurunya dan bukan melalui kegiatan eksplorasi.

Pentingnya kemampuan pemahaman matematis ini ternyata belum sejalan dengan prestasi siswa Indonesia di mataInternasional. Hasil penelitian The Third International Mathematics and Science Study(TIMSS) 2011 menyatakan bahwa siswa Indonesia kelas VIII dalam penerapan pengetahuan dan pemahaman konsep matematika berada pada urutan ke-38dari 45 negaradengan nilai rata-rata 386 . Selain kemampuan yang berkaitan dengan kemampuan pemahaman matematis, perlu juga dikembangkan sikap menghargai kegunaan matematika dalam kehidupan, yaitu memiliki rasa ingin tahu, perhatian, dan minat dalam mempelajari matematika, serta sikap ulet dan percaya diri dalam memecahkan masalah (Depdiknas, 2006).

Sikap siswa terhadap matematika tidak dapat dipisahkan dari kemampuan matematis siswa dan terhadap hasil belajar 
siswa. Menurut hasil penelitian Siskandar (2008) bahwa terdapat hubungan positif antara sikap siswa terhadap matematika dengan hasil belajar matematika. Artinya bahwa semakintinggi sikap positif siswa terhadap matematika, maka semakin tinggi pula hasil belajarnya dalam pelajaran matematika.

Selain itu, terdapat keterkaitan antara sikap dengan proses pembelajaran matematika, seperti dijelaskan Ruseffendi (2006) bahwa untuk menumbuhkan sikap positif terhadap matematika, pembelajaran harus menyenangkan, mudah dipahami, tidak menakutkan, dan ditunjukkan kegunaannya. Hal tersebut dapat diwujudkan antara lain bila matematika diajarkan sesuai dengan lingkungan dan pengetahuan siswa. Menurut Darhim (2004) sikap siswa terhadap matematika tersebut diduga terkait kemampuan awal siswa atau kelompok siswa (lemah dan pandai) di kelasnya. Selain dikaitkan dengan kelompok siswa (lemah dan pandai) seperti di atas, sikap siswa terhadap matematika juga diduga terkait dengan kelompok sekolah (baik dan sedang).

Salah satu pembelajaran yang bisa digunakan adalah pembelajaran Peer Instruction with Structured Inquiry (PISI). Peer Instruction(PI) adalah sebuah pedagogi yang banyak digunakan dalam perkuliahan yang diselingi dengan pertanyaan konseptual singkat (Conceptest) yang dirancang untuk mengungkapkan kesalahpahaman dan untukmelibatkan siswa agar aktif dalam kuliah sedangkan Structured Inquiry merupakan jenis inkuiri dengan tingkatan terendah dimana siswa ditugaskan untuk melakukan penyelidikan berdasarkan masalah yang diberikan oleh guru dan siswa juga menerima seluruh instruksi pada setiap tahap-tahapnya.

Pembelajaran Peer Instruction with Structured Inquiry (PISI) merupakan pembelajaran yang melibatkan siswa secara aktif. Dengan aktifnya siswa dalam pembelajaran, akan meningkatkan kemampuan pemahaman siswa terhadap konsep-konsep matematika, karena siswa diarahkan untuk menyusun prosedur dan mengingat kembali materi yang disampaikan dalam memecahkan masalah. Dengan demikian, dapat diprediksi bahwa penerapan pembelajaran Peer Instruction with Structured Inquiry (PISI) dapat meningkatkan kemampuan pemahaman matematis siswa.

Tujuan penelitian ini dilakukan adalah untuk mengetahui apakah peningkatan kemampuan pemahaman matematis siswa yang memperoleh pembelajaran Peer Instruction with Structured Inquiry (PISI) lebih baik daripada siswa yang memperoleh pembelajaran matematika secara konvensional dan bagaimana sikap siswa terhadap pembelajaran Peer Instruction with Structured Inquiry (PISI).

\section{KEMAMPUAN PEMAHAMAN MATEMATIS}

Dalam kamus besar Bahasa Indonesia (Depdiknas, 2006) dijelaskan bahwa kata "pemahaman" berasal dari kata kerja "paham", yang berarti mengerti benar atau tahu benar. Seseorang dikatakan mengerti benar terhadap suatu konsep jika dapat menjelaskan kembali dan menarik kesimpulan terhadap konsep tersebut.

Anderson et al. (Kesumawati, 2011), menyatakan understand is defined as constructing the meaning of instructional messages, including oral, written, and graphic communication. Menurut pendapat tersebut, siswa dikatakan memahami sesuatu jika mereka mampu mengkonstruksi makna dari pesan-pesan pengajaran seperti komunikasi lisan, tulisan, dan grafik. Tingkat pemahaman seseorang terhadap suatu konsep dapat dilihat dari jenis-jenis pemahaman yang dimilikinya.

Skemp (Sumarmo, 2010) menyatakan bahwa terdapat dua jenis kemampuan pemahaman, yaitu: 1) Pemahaman instrumental yang artinya 
hapal sesuatu secara terpisah atau dapat menerapkan sesuatu pada perhitungan rutin/sederhana, mengerjakan sesuatu secara algoritmik. Pada pemahaman ini siswa hanya menghapal rumus dan urutan pengerjaan dan algoritma saja; 2) Pemahaman relasional yang berarti dapat melakukan perhitungan secara bermakna pada permasalahan-permasalahan yang lebih luas, termuat skema atau struktur yang dapat digunakan pada penyelesaian yang memuat masalah yang lebih luas, dapat mengaitkan suatu konsep/prinsip lainnya dan sifat pemakaiannya lebih bermakna.

Polya (Sumarmo, 2010), menyatakan empat tingkat pemahaman matematis suatu hukum, yaitu pemahaman mekanikal, pemahaman induktif, pemahaman rasional dan pemahaman intuitif. Pemahaman mekanikal berarti dapat mengingat dan menerapkan hukum secara benar. Pemahaman induktif berarti menerapkan hukum ke dalam kasus sederhana dan meyakini bahwa hukum bisa diberlakukan untuk kasus yang serupa. Pemahaman rasional berarti dapat membuktikan kebenaran dari suatu hukum. Pemahaman intuitif berarti meyakini hukum tanpa keragu-raguan dan memberikan prediksi dengan bukti kebenarannya.

Polattsek (Sumarmo, 2010), membedakan dua jenis pemahaman, yaitu: (1) Pemahaman komputasional, yaitu dapat menerapkan sesuatu pada perhitungan rutin/sederhana, atau mengerjakan sesuatu secara algoritmik saja; (2) Pemahaman fungsional, yaitu dapat mengkaitkan sesuatu dengan hal lainnya secara benar dan menyadari proses yang dilakukan.

Copeland (Sumarmo, 2010), kemampuan pemahaman ada dua jenis, yaitu: (1) Knowing how to, yaitu mengerjakan sesuatu secara rutin/algoritmik; (2) Knowing, yaitu dapat mengerjakan sesuatu dengan sadar akan proses yang dikerjakannya.

Sementara itu, Ruseffendi (2006: 221) menyatakan tiga macam pemahaman yaitu: (1) pengubahan (translation) dalam matematika misalnya mampu mengubah soal kata-kata ke dalam simbol dan sebaliknya; (2) pemberian arti (interpretation), misalnya mampu mengartikan suatu kesamaan; pembuatan ekstrapolasi (extrapolation), misalnya mampu memperkirakan suatu kecenderungan dari diagram.

\section{PEMBELAJARAN PEER INSTRUCTION WITH STRUCTURED INQUIRY (PISI)}

Pembelajaran PISI merupakan pembelajaran yang berlandaskan Peer Instructionyang disertai dengan Structured Inquiry. Peer instruction yang diperkenalkan oleh Mazur (Wikipedia, 2012) pada tahun 1990 merupakan pembelajaran pengajaraninteraktifyang dikembangkan di Harvard University.

Peer Instruction(PI) adalah sebuah pembelajaran yang digunakan secara luas dalam perkuliahan yang diselingi dengan pertanyaan konseptual singkat (Conceptest) yang dirancang untuk mengungkapkan kesalahpahaman dan untukmelibatkan siswa agar aktif dalamkuliah, sebagaimana yang diungkapkan oleh Mazur et al. (2002): "Peer Instruction (PI) is a widely used pedagogy in which lectures are interspersed with short conceptual questions (ConcepTests) designed to reveal common misunderstandings and to actively engage students in lecture courses". Restall et al. (2009) mengemukakan bahwa "Peer Instruction (or PI for short) is a simple and effective technique you can use to make lectures more interactive, more engaging, and more effective learning experiences".

Inkuiri berasal dari bahasa Inggris "inquiry" yang secara harfiah berarti pertanyaan atau penyelidikan.Pembelajaran dengan metode inkuiri pertama kali dikembangkan oleh Richard Suchman tahun 1962, yaitu siswa melakukan kegiatan, mengumpulkan dan menganalisis data, sampai akhirnya siswa menemukan jawaban dari pertanyaan itu (Joyce et al., 2000). 
Menurut The National Science Education Standard, inkuiri dapat dimanfaatkan penggunaannya dalam hal: (a) penguasaan konsep, yaitu siswa memiliki kesempatan untuk membangun konsep dan pola, serta (b) keterampilan yang berorientasi dalam hal mengajukan pertanyaan, membuat hipotesis, mendesain dan melaksanakan penyelidikan, penjelasan dan mengkomunikasikan serta mempertahankan argumen (Hofstein etal., 2005).

Berdasarkan The National Research Council (NRC, 2000) terdapat tiga jenis pembelajaran inkuiri berdasarkan tingkatannya, yaitu: 1) Inkuiri Terstruktur (Structured Inquiry) merupakan jenis inkuiri dengan tingkatan terendah. Pada inkuiri terstruktur, siswa melakukan penyelidikan berdasarkan masalah yang diberikan oleh guru, selain itu juga siswa menerima seluruh instruksi pada setiap tahap-tahapnya. 2) Inkuiri Terbimbing (Guided Inquiry) merupakan jenis inkuiri dengan tingkatan inkuiri yang lebih kompleks dibandingkan inkuiri terstruktur. Pada inkuiri terbimbing siswa terlibat langsung dalam proses pembelajaran melalui penyelidikan dari permasalahan ilmiah dan prosedur yang diberikan oleh guru, kemudian siswa menentukan proses dan solusi dari permasalahan tersebut hingga akhirnya siswa dapat membuat kesimpulan. 3) Inkuiri Terbuka (Open Inquiry) merupakan jenis inkuiri dengan tingkatan inkuiri tertinggi. Selama proses pembelajaran ini, siswa terlibat langsung dalam proses pembelajaran dengan melakukan penyelidikan terhadap topik yang berhubungan dengan pertanyaan atau masalah, merancang desain eksperimen hingga siswa dapat memberikan kesimpulan sendiri melalui setiap tahap proses dalam open inquiry.

Pembelajaran PISI terdiri dari 2 bagian, yaitu Peer Instruction (PI) dan Structured Inquiry (SI). Tahapan Peer Instruction (PI) terdiri dari 3 tahapan utama, yaitu Brief Lecture (BL), Concept Test $(C T)$ dan Remaining Explanation or Demonstration or Hands-On Activity $(R D H)$ yang secara tidak langsung menuju ke tahapan Structured Inquiry (SI) yang terdiri dari 5 tahapan, yaitu Engagement, Exploration, Explanation, Elaboration dan Evaluation.

\section{SIKAP SISWA}

Menurut Syah (2005) dalam arti yang sempit sikap adalah pandangan atau kecenderungan mental.Dengandemikian, pada prinsipnya sikap itu bisa kita anggap suatu kecenderungan siswa untuk bertindak dengan cara tertentu. Menurut Bruno (Syah, 2005), sikap (attitude) adalah kecenderungan yang relatif menetap untuk bereaksi dengan cara baik atau buruk terhadap orang atau barang tertentu. Menurut Ruseffendi (2005), sikap seseorang terhadap sesuatu itu erat sekali kaitannya dengan minat; sebagian bisa tumpang tindih, sebagian dari sikap itu merupakan akibat minat. Jika seorang siswa berminat pada matematika, maka siswa tersebut akan bersikap positif terhadap pelajaran matematika.

Menurut Suherman dkk (2003) ada beberapa hal yang bisa diperoleh guru dengan melaksanakan evaluasi sikap antara lain: 1) Memperoleh balikan (feed back) sebagai dasar untuk memperbaiki proses belajar mengajar dan program pengajaran remedial. 2) Memperbaiki perilaku diri sendiri (guru) maupun siswa. 3) Memperbaiki atau menambah fasilitas belajar yang masih kurang. 4) Mengetahui latar belakang kehidupan siswa yang berkenaan dengan aktivitas belajarnya.

Sikap dapat bersifat negatif dan dapat pula bersifat positif. Sikap negatif memunculkan kecenderungan untuk menjauhi, membenci, menghindari ataupun tidak menyukai keberadaan suatu objek. Sedangkan sikap positif memunculkan kecenderungan untuk menyenangi, mendekati, menerima atau bahkan mengharapkan kehadiran objek tertentu (Rukminto, 1994). 
Siswa yang memiliki sikap positif terhadap matematika memiliki ciri antara lain terlihat sungguh-sungguh dalam belajar matematika, menyelesaikan tugas dengan baik dan tepat waktu, berpartisipasi aktif dalam diskusi, mengerjakan tugastugas pekerjaan rumah dengan tuntas, dan selesai pada waktunya (Saragih, 2007).Sikap belajar yang positif akan menimbulkan intensitas kegiatan yang lebih tinggi dibanding dengan sikap belajar yang negatif (Djaali, 2007).

\section{METODE PENELITIAN}

Berdasarkan latar belakang dan rumusan masalah, penelitian yang digunakan adalah quasi experiment. Dalam hal ini peneliti menerima keadaan subjek seadanya. Adapun desain penelitian yang digunakan dalam penelitian ini adalah desain kelompok kontrol pretes-postes yang disebut juga desain kelompok kontrol non-ekuivalen. Desain penelitian yang digunakan sebagai berikut:

O X O

$\mathrm{O}$

$\mathrm{O}$

Sumber : (Ruseffendi, 2005)

Keterangan:

$\mathrm{O}$ : pretes dan postes kemampuan pemahaman dan pemecahan masalah matematis

X : perlakuan berupa pembelajaran Peer Instruction with Structured Inquiry (PISI)

Populasi penelitian ini adalah siswa Sekolah Menengah Pertama (SMP) Negeri 1 Ciamis kelas VIII tahun ajaran 2012/2013. Peneliti menggunakan sampel yang diambil dari populasi. Pemilihan sampel dalam penelitian ini dilakukan dengan cara purposive sampling. Dari 9 kelas yang ada, kemudian dipilih 2 kelas yaitu kelas VIII-B dan kelas VIII-C yang akan dijadikan sebagai satu kelas eksperimen yaitukelas yang mendapat pembelajaran Peer Instruction with
Structured Inquiry (PISI) dan satu kelas kontrol yaitu kelas yang mendapat pembelajaran konvensional. Alat uji yang digunakan adalah instrumen tes berupa tes kemampuan pemahaman matematis dan instrumen non tes berupa skala sikap, wawancara dan lembar observasi. Pengolahan data menggunakan uji gain ternormalisasi dan uji statistik berupa uji $t^{\prime}$ dan uji Mann-Whitney.

\section{HASIL DAN PEMBAHASAN KEMAMPUAN PEMAHAMAN MATEMATIS}

Kemampuan awal pemahaman matematis diperoleh dari hasil tes yang disebut dengan pretes. Pretes diberikan pada siswa di kelas eksperimen dan kelas kontrol. Sebelum siswa di kelas eksperimen memperoleh pembelajaran dengan Peer Instruction with Structured Inquiry (PISI) dan siswa kelas kontrol memperoleh pembelajaran konvensional diberikan terlebih dahulu tes berupa soal pemahaman matematis untuk memperoleh kemampuan awal pemahaman matematis siswa. Hasil uji normalitas kemampuan awal pemahaman matematis disajikan pada Tabel 1 berikut.

Tabel 1 Hasil Uji Normalitas Kemampuan Awal Pemahaman Matematis

\begin{tabular}{lcc}
\hline Kelas & $\begin{array}{c}\text { Shapiro- } \\
\text { Wilk } \\
\text { (sig) }\end{array}$ & Kesimpulan \\
\hline PISI & 0,000 & $\begin{array}{c}\text { Tidak } \\
\text { Normal }\end{array}$ \\
\hline Konvensional & 0,169 & Normal \\
\hline
\end{tabular}

Berdasarkan Tabel 1, nilai signifikansi kemampuan awal pada kelas eksperimen 0 , $000<\alpha=0,05$ dan pada kelas kontrol $0,169>\alpha=0,05$. Hal ini berarti pada taraf signifikansi 5\%, kemampuan awal pemahaman matematis siswa pada kelas eksperimen berdistribusi tidak normal dan kelas kontrol berdistribusi normal, maka $H_{0}$ ditolak. Dengan demikian, untuk melihat kemampuan awal pemahaman matematis siswa, selanjutnya 
menggunakan statistik nonparametris Mann-Whitney. Hasil pengolahan data uji nonparametris Mann-Whitney dengan bantuan SPSS 17.0 for windows disajikan pada Tabel 2 berikut.

Tabel 2 Hasil Uji Nonparametris MannWhitney Kemampuan Awal Pemahaman Matematis

\begin{tabular}{lc}
\hline $\begin{array}{l}\text { Mann- } \\
\text { Whitney } \boldsymbol{U}\end{array}$ & $\begin{array}{c}\text { Kemampuan Awal } \\
\text { Pemahaman } \\
\text { Matematis }\end{array}$ \\
\hline $\begin{array}{l}\text { Asymp. } \\
\text { Sig.(2-tailed) }\end{array}$ & 0,035 \\
\hline
\end{tabular}

Berdasarkan Tabel 2 di atas, nilai signifikansi 2-tailed pada uji nonparametris Mann-Whitney untuk kemampuan awal pemahaman matematis siswa adalah $0,035<\alpha=0,05$, maka $H_{0}$ ditolak, artinya terdapat perbedaan yang signifikan antara kemampuan awal pemahaman matematis antara siswa yang mendapatkan pembelajaran matematika melalui Peer Instruction with Structured Inquiry (PISI) dengan kemampuan awal pemahaman matematis siswa yang mendapatkan pembelajaran secara konvensional. Untuk melihat bagaimana peningkatannya, dilakukan uji perbedaan rata-rata terhadap peningkatan kemampuan pemahaman matematis pada kedua kelas.

Rata-rata peningkatan kemampuan pemahaman matematis dianalisis dengan $\mathrm{N}-$ Gain. Hipotesis yang akan diuji adalah sebagai berikut:

"Peningkatan kemampuan pemahaman matematis siswa yang memperoleh pembelajaran Peer Instruction with Structured Inquiry (PISI) lebih baik daripada siswa yang memperoleh pembelajaran matematika secara konvensional."

$H_{0}: \mu_{p p e}=\mu_{p p k}$,

Tidak terdapat terdapat perbedaan rata-rata peningkatan kemampuan pemahaman matematis antara siswa yang mendapatkan pembelajaran matematika melalui PISI dan siswa yang mendapatkan pembelajaran secara konvensional.

$H_{1}: \mu_{p p e}>\mu_{p p k}$,

Rata-rata peningkatan kemampuan pemahaman matematis antara siswa yang mendapatkan pembelajaran matematika melalui PISI lebih tinggi daripada siswa yang mendapatkan pembelajaran secara konvensional.

Hasil uji normalitas peningkatan kemampuan pemahaman matematis disajikan pada Tabel 3 berikut.

Tabel 3 Hasil Uji Normalitas Peningkatan Kemampuan Pemahaman Matematis

\begin{tabular}{lcc}
\hline Kelas & $\begin{array}{c}\text { Shapiro- } \\
\text { Wilk } \\
\text { (sig) }\end{array}$ & Kesimpulan \\
\hline PISI & 0,119 & Normal \\
\hline Konvensional & 0,243 & Normal \\
\hline
\end{tabular}

Berdasarkan Tabel 3 di atas, nilai signifikansi peningkatan pada kelas eksperimen $0,119>\alpha=0,05$, dan pada kelas kontrol 0,243 $>\alpha=0,05$, maka $H_{0}$ diterima artinya kedua kelas berdistribusi normal. Dengan demikian, pengolahan data dilanjutkan dengan uji homogenitas. Hasil pengolahan data uji homogenitas dengan uji Levene dengan bantuan SPSS 17.0 for windows disajikan pada Tabel 4 berikut:

Tabel 4 Hasil Uji Homogenitas

Peningkatan Kemampuan

Pemahaman Matematis

\begin{tabular}{|c|c|}
\hline $\begin{array}{l}\text { Levene's } \\
\text { equality fort for } \\
\text { varances }\end{array}$ & $\begin{array}{c}\text { Peningkatan } \\
\text { Kemampuan } \\
\text { Pemahaman } \\
\text { Matematis }\end{array}$ \\
\hline Signification & 0,000 \\
\hline
\end{tabular}

Berdasarkan Tabel 4 di atas, nilai signifikansi pada uji homogenitas Levene untuk peningkatan kemampuan pemahaman matematis siswa adalah 0,000 $<\alpha=0,05$, maka $H_{0}$ ditolak. Dengan kata lain, data dari kedua kelompok sampel memiliki varians yang berbeda. 
Hasil uji normalitas dan uji homogenitas menunjukkan bahwa peningkatan pada kedua kelas berdistribusi normal dan memiliki varians tidak homogen. Selanjutnya untuk melihat bagaimana peningkatan kemampuan pemahaman matematis pada kedua kelas dilakukan menggunakan uji t'independent sample test.

Hasil pengolahan uji t'independent sample test dengan bantuan SPSS 17.0 for windows disajikan pada Tabel 5 berikut.

Tabel 5 Hasil Uji t'Independent Sample Test Peningkatan Kemampuan Pemahaman Matematis

\begin{tabular}{cc}
\hline $\begin{array}{c}\text { t'independent sample } \\
\text { test }\end{array}$ & $\begin{array}{c}\text { Peningkatan } \\
\text { Kemampuan } \\
\text { Pemahaman } \\
\text { Matematis }\end{array}$ \\
\hline Sig (2-tailed) & 0,000 \\
\hline Sig (1-tailed) & 0,000 \\
\hline
\end{tabular}

Berdasarkan Tabel 5, nilai signifikansi 1-tailed uji t'independent sample test peningkatan kemampuan pemahaman matematis siswa adalah $0,000,<\alpha=$ 0,05, maka $H_{0}$ ditolak. Dengan kata lain, rata-rata peningkatan kemampuan pemahaman matematis siswa yang mendapatkan pembelajaran matematika melalui Peer Instruction with Structured Inquiry (PISI) lebih baik daripada siswa yang mendapatkan pembelajaran secara konvensional. Hal ini berarti pada taraf signifikansi 5\%, peningkatan kemampuan pemahaman matematis siswa yang mendapatkan pembelajaran matematika melalui Peer Instruction with Structured Inquiry (PISI) lebih baik daripada siswa yang mendapatkan pembelajaran secara konvensional.

\section{SKALA SIKAP SISWA}

Secara khusus, kelas eksperimen diberi angket untuk mengetahui sikap siswa setelah mengikuti pembelajaran Peer Instruction with Structured Inquiry (PISI). Angket yang diberikan terdiri dari 30 pertanyaan yang memuat tujuh indikator, meliputi; (1) Pandangan siswa terhadap matematika; (2) Pandangan siswa terhadap manfaat mempelajari matematika; (3) Pandangan siswa terhadap pembelajaran PISI; (4) Pandangan siswa terhadap diskusi dalam pembelajaran PISI; (5) Pandangan siswa terhadap penggunaan LKS dalam pembelajaran PISI; (6) Pandangan siswa terhadap soal-soal kemampuan pemahaman dan soal-soal kemampuan pemecahan masalah siswa; (7) Pandangan siswa terhadap hubungan soal dengan materi yang sudah dipelajari.

Hasil penelitian menunjukkan bahwa siswa menunjukkan yang positif terhadap pembelajaran Peer Instruction with Structured Inquiry (PISI). Berdasarkan hasil analisis ditemukan bahwa faktor pembelajaran yang diterapkan berpengaruh terhadap sikap siswa, beberapa faktor yang berpengaruh diantaranya: dengan adanya diskusi dan sistem voting dalam pertanyaan konseptual, memungkinkan siswa untuk lebih terbiasa dalam mengemukakan pendapat, bertanya, mempresentasikan di depan kelas sehingga siswa menjadi aktif dan lebih mudah dalam menghadapi setiap permasalahan yang diberikan guru melalui LKS.

\section{SIMPULAN}

Berdasarakan hasil analisis dan pembahasan, diperoleh kesimpulan bahwa peningkatan kemampuan pemahaman matematis siswa yang mendapatkan pembelajaran Peer Instruction with Structured Inquiry (PISI) baik daripada siswa yang mendapat pembelajaran konvensional, meskipun rata-rata peningkatannya berada pada klasifikasi sedang. Secara keseluruhan, sikap siswa yang mendapat pembelajaran Peer Instruction with Structured Inquiry (PISI) menunjukkan sikap yang positif. 


\section{DAFTAR PUSTAKA}

Artikel Non-Personal, 31 oktober 2012, Peer Instruction, Wikipedia Bahasa Inggris, http://en.wikipedia.org/wiki/Peer instruction, [12 januari 2013].

Darhim, (2004). Pengaruh Pembelajaran

Matematika

Kontekstual

terhadap Hasil Belajar dan Sikap Siswa Sekolah Dasar Kelas Awal dalam Matematika. Disertasi pada SPs UPI. Bandung: Tidak diterbitkan.

Departemen Pendidikan Nasional. (2006). Kurikulum Tingkat Satuan Pendidikan. Jakarta: Pusat Kurikulum Balitbang Depdiknas.

Hamidah. (2011). Pengaruh Model Pembelajaran ARIAS terhadap Kemampuan Pemahaman Matematis Siswa SMP Ditinjau dari Tingkat Kecerdasan Emosional. Tesis pada SPs UPI. Bandung: Tidak diterbitkan.

Hendriana, H. (2009). Pembelajaran dengan Pendekatan Metaphorical Thinking untuk Meningkatkan Kemampuan Pemahaman Matematik, Komunikasi matematik, dan Kepercayaan Diri Siswa Sekolah Menengah Pertama. Disertasi pada SPs UPI. Bandung: Tidak diterbitkan.

Joyce et al. (2000). Models of Teaching, Sixth Edition. Boston: Allyn and Bacon.

Kesumawati, N. (2011). Peningkatan Kemampuan Pemahaman, Pemecahan Masalah dan Disposisi Matematis Siswa SMP melalui Pendekatsn Matematika Realistik. Disertasi pada SPs
UPI. Bandung : Tidak diterbitkan.

Mazur et al. (2002). Peer Instruction : Result from a Range of Classrooms. The Physic Teacher. Volume 40.

National Council of Teachers of Mathematics. (2000). Principles and Standards for School Mathematics. Reston, VA: NCTM.

Oktavien, Y. (2012). Meningkatkan Kemampuan Pemahaman dan Pemecahan Masalah Matematis Siswa Sekolah Menengah Atas melalui Pembelajaran Kooperatif Tipe Jigsaw : Studi Eksperimen Di Sma Negeri 1 Rengat. Tesis pada SPs UPI. Bandung: Tidak diterbitkan.

Restall et al. (2009). Using Peer Instruction to teach Philosophy, Logic and Critical Thinking. Journal of Computer Assisted Learning. Volume 32. No. 1.

Ruseffendi, E.T. (2005). Dasar-dasar Penelitian Pendidikan dan Bidang Noneksakta Lainnya.. Bandung: Tarsito.

Ruseffendi, E.T. (2006). Pengantar kepada Membantu Guru Mengembangkan

Kompetensinya dalam Pembelajaran Matematika untuk Meningkatkan CBSA. Bandung: Tarsito.

Siskandar. (2008). Sikap dan Motivasi Siswa dalam Kaitannya dengan Hasil Belajar Matematika di SD. Jurnal Pendidikan dan Kebudayaan. Volume 072. Hal 438-451. 
Suherman, E, dkk. (2003). Strategi

Pembelajaran Matematika

Kontemporer. JICA:

Universitas Pendidikan

Indonesia.

Sumarmo, U. (2003). Pembelajaran

Keterampilan Membaca

Matematika Pada Siswa Sekolah

Menengah. Makalah National

Seminar On Science And

Mathematics. FMIPA-UPI in

cooperation with JICA. Dirjen

Dikti Depdiknas.

Sumarmo, U. (2010). Pendidikan Karakter, Berpikir dan Disposisi Logis, Kritis, dan Kreatif dalam Pembelajaran Matematika. Makalah pada perkuliahan Evaluasi Matematika 2011 SPS UPI: Tidak Diterbitkan.

Syah, M. (2005). Psikologi Belajar. Jakarta: PT. Raja Grafindo Persada.

Tim TIMSS Indonesia. (2011). Survei Internatsional TIMSS. [Online]. Tersedia:http://litbangkemdiknas .net/detail.php?id=214.

Oktober 2012] 